\title{
Visions of prosperity and conspiracy in Timor-Leste
}

\author{
Judith Bovensiepen
}

\begin{abstract}
In Timor-Leste, visions of radical societal transformation and future wealth derived from gold and oil are accompanied by concerns that outsiders might be conspiring to rob the country of its riches, as well as conjuring up dystopian scenarios of sinister plots and future mayhem. Examining national narratives and local accounts, this article argues that visions of prosperity and visions of conspiracy are two sides of the same coin; both are embedded in an understanding that power works in invisible ways. In discussing these visions in relation to the literature on "conspiracy theories" and "cargo cults" (terms that have recently been imported to the study of Timor-Leste), it explores the critical potential of these visions. Whereas the labels "conspiracy theory" and "cargo cult" create distinctions between the "rational" perspective of the West and the "irrationality" of nonWestern others, as practices these visions end up collapsing such distinctions by appropriating the power of the outside.
\end{abstract}

Keywords: cargo cults, conspiracy theories, critiques of power, occult cosmologies, the politics of oil

In 1987-1988, the Portuguese-Timorese priest Jorge Barros Duarte identified three "nativist movements" in East Timor, arguing that these had "cargoistic" elements. The movements combined Christian with "nativist" practices and were critical of the status quo, thus advancing "a vision of a new society and a new life" (Duarte 1987-1988: 51). The priest was not the only one who speculated about the existence of "cargo cults" in East Timor. When in 2011 the East Timorese government (by then independent from Indonesia) launched the Strategic Development Plan, which contained plans for a massive petroleum development project along the south coast of the country, several "internationals" working for the aid industry in the country likened these plans to a cargo cult. Australia is still today making claims to oil and gas reserves in the Timor Sea, which according to international maritime law belong to Timor-Leste. Plans for an onshore petroleum infrastructure on the south coast are explicitly part of Timor-Leste's struggle for national sovereignty, since Australia refused to settle on permanent maritime boundaries and pushed Timor-Leste into a resourcesharing agreement.

When Timor-Leste regained independence in 2002, the anthropological fascination with the diverse range of phenomena (mainly in Melanesia) labeled falsely or not as "cargo cults" 
had already peaked and waned. After an initial proliferation of writing on the subject in the 1950s and 1960s (and resurgences in the 1970s and 1980s), the contested label "cargo cult," invented in 1945, had been largely discredited (Jebens 2004: 1-2). Not only does it import negative connotations of "irrationality," but it also exaggerates the differences between "Melanesia" and "the West" (Hermann 2004). Furthermore the label was seen to misrepresent what was actually happening in Melanesia and came to be seen as ideologically suspect (Robbins 2004: 243). In light of such discreditation, the aim of this article is not to establish whether or not there are cargo cults in Timor-Leste. Nevertheless, it seeks to take seriously the hopes for social change that are expressed by people whose ideas have been described as "cargoistic," by which I mean the "visions of prosperity" that are a vital motivating force behind present-day development in the country.

These ideas about prosperity labeled as "cargoistic" are often linked to rumors about conspiracy. When internal conflicts broke out in Timor-Leste in 2006, for example, there were widespread rumors that foreigners, specifically Australians or Indonesians, were meddling with national politics, seeking to oust the left-wing FRETILIN government in order to put economically liberal rivals into power, prompting media reports about left-wing "conspiracy theories" (e.g. Aarons 2006). Across Timor-Leste, visions of radical societal transformation and future wealth derived from gold or oil are frequently accompanied by concerns that outsiders might be conspiring to rob the country of its riches. Labeling such concerns "conspiracy theories" is also a way of trying to invalidate criticisms of foreign intervention.

This article explores utopian visions of prosperity in relation to dystopian visions that express suspicions about sinister plots, as well as conjuring up scenarios of future mayhem, war, or foreign exploitation. Examining national narratives and local accounts, I argue that visions of prosperity and visions of conspiracy are two sides of the same coin; both are embedded in an understanding of the invisible workings of power, both are critiques of power and attempts to appropriate it. The conjoining of these phenomena at an empirical level also allows me to link them analytically-using insights from anthropological debates about the contested label "cargo cult" to think about certain aspects in the literature on "conspiracy theories" and vice versa.

This article distinguishes between, on the one hand, the labels "cargo cult" and "conspiracy theory," and on the other hand, the practices of envisioning prosperity and conspiracy. To make this distinction it draws on Pelkmans and Machold's (2011) argument that there is a difference between labeling a certain idea a conspiracy theory, and the practice of theorizing about conspiracies. Labeling and theorizing are frequently carried out from different positions in a field of power. Pelkmans and Machold (2011: 67, 77) stress that conspiracy theory labels tend to be produced by people in positions of power and are "a tool for those in control" because such labels are used to discredit those suspicious of power. By contrast, "conspiracy theorizing," they argue (2011: 77), is a means "to render an inexplicable world comprehensible," and thereby "challenge real conspiracies."

The same might be said about the label "cargo cults." Just like the label "conspiracy theory," the term "cargo cult" can be used to present people as irrational, counter-productive, or entirely other, thereby reproducing the marginalization of those to whom such labels apply and opening them up to ridicule. It depends on who is using such labels. I thus propose to distinguish between the label "cargo cult" and the practice of envisioning radical societal transformation, as these practices stem from very different positions in a field of power.

The research on which this article is based draws on over thirty months of fieldwork between 2005 and 2015 in three different localities in Timor-Leste: in Laclubar (the central highlands), Suai-Covalima (the south coast), and the capital city Dili. The Indonesian military had occupied the half-island of East Timor for nearly 
a quarter of a century (1975-1999), taking advantage of the political instabilities of the decolonization process, when national parties and an independence movement were developing in the former Portuguese colony. The country regained independence in 2002 and is now officially referred to as "The Democratic Republic of Timor-Leste."

\section{Visions of prosperity}

Since 2011, the East Timorese government has been initiating a variety of gigantic development projects. These include a massive onshore petroleum infrastructure project, the Tasi Mane petroleum corridor, and special economic zones in the enclave of Oecussi and on the island of Atauro (Meitzner Yoder 2015). The plans for these projects-including computer-generated videos and photographs of artificially designed cities, a modern six-lane highway, and new airports-have been circulated across the country and raise intense hopes and expectations among the population. Several research participants told me that they thought that in 10 or 20 years, Timor-Leste would look like Portugal, Singapore, Australia, or Indonesia (see Bovensiepen, Filipe, and Freitas forthcoming). One may say that the utopian hopes for radical societal transformation once associated with independence (Nygaard-Christensen 2010), are now associated with oil wealth. As Bubandt (2004) has said in relation to his research in Maluku (Halmatera), modernity is its very own cargo cult with millenarian elements. Along similar lines the Australian academic James Scambary (personal communication) has argued that the ideology of neoliberalism could be seen as a cargo cult. To counter representations of East Timorese as cargoistic, the Timorese politician Fidelis Magalhães (personal communication) has suggested that the UN transitional government in East Timor that governed the country from 1999 to 2002 could also be seen as a kind of cargo cult, as it promised radical societal transformation to prosperity through democratisation.
Hopes of rapid prosperity cannot just be found at the national level but were also vivid during my research in the coastal area of SuaiCovalima and the highlands of the Laclubar subdistrict. With the onslaught of the Indonesian occupation in 1975, and during the violent interactions between East Timorese political parties that preceded it, the inhabitants of the rural areas of Laclubar were forcibly displaced: in the mid- to late 1970s, the Indonesian military resettled residents from the village of Funar in Laclubar Town. In the mid- to late 1990s, after nearly two decades of forced exile, many of them returned to their ancestral lands, where they have since actively sought to rebuild their place of origin. When the villagers returned to their ancestral land, a number of them maintained that they are the potential owners of marvelous riches-and that they will realize ownership if they achieve the appropriate relationship with their ancestral landscape. Some argued that an abundance of gold lies beneath the ancestral sites or is stored inside ancestral houses; indeed, some told stories of how during ancestral times, golden discs would hover over the land. To re-create such wealth today, according to this view, ancestral relations must be reinvigorated not only by moving back to the ancestral land but through ritual reinauguration of ancestral houses and places-conspiring with invisible forces would usher in a time of wealth and prosperity.

This connection between wealth, the land, and the ancestors was a central topic in many narratives. Some of them recount the encounters of former rulers with a golden star, something which resonates both with biblical accounts of a guiding star, as well as with the Morning Star associated with independence in West Papua (Rutherford 2003). In Laclubar, the golden star is described as the embodiment of lulik land, lulik being a term frequently translated as "sacred," "forbidden," or "potent"-a potency that is seen as distinctly indigenous and associated with the ancestors and with the underground. Moreover, as I have shown elsewhere, in ancestral narratives gold is a metonym for lulik (Bov- 
ensiepen 2015). It is through the mobilization and help of this lulik potency that ancestral rulers are said to have gained independence from neighboring regions.

The association between lulik and gold is also clear from more contemporary accounts. One man told me for example that during the Indonesian occupation he had found a small piece of gold, the size of a peanut, in his pocket. After that, he started traveling in his dreams: he would fly around and into the mountains near Laclubar Town and in the morning he would wake up near the lulik site. He was very frightened by these unwanted journeys, and so he tried to throw the gold away, but it kept on reappearing in his pocket. This account echoes an oral tradition about the ruler of Laclubar (Dom Geraldo), who "gained independence" from the neighboring domain by descending into an underground tunnel inside a lulik mountain. Independence, here, is associated not just with gold in the shape of a star but also with the underground. My friend's unwanted travels through the underground, triggered by the piece of gold, is similarly a way in which he gains access to a realm thus far unfamiliar to him; dreams make this aspect visible and allow him-albeit against his will-access to unknown aspects of life.

There were other related narratives that mentioned gold. A member of the ruling house in Laclubar Town told me in secret, and with an expression of wonder, that when his origin house was inaugurated recently, a cloud of golden stars fell from the sky. He also maintained that the British monarchy had financed the construction of his origin house. Comparable claims have been made by political leaders in the capital city, Dili. The leader of the Timor's People's Party (PPT), Jacob Xavier, contended that his lulik house was Buckingham Palace and that gold from Timor's lulik houses was stolen to establish the World Bank (Kammen 2009: 398).

It is a common feature of these accounts that the source of prosperity is associated with the land (and more specifically the underground) and with ancestral houses. These houses, which are units of identification and social organiza- tion, are divided into foreign and indigenous houses, representing the political and ritual spheres respectively. The members of the autochthonous houses, which are called "the guardians/people of the land," claim that their ancestors emerged directly from the land. Because the land is thought to have given birth to the primordial ancestors, it is considered to be the "trunk," "origin," or "center" of life. I was also told that humanity descends from a lulik site in Laclubar Town, called Balulin. This place, marked by a hole in the ground, is considered to be the birthplace of the first human ancestors, who are sometimes referred to as Adam and Eve. One man told me that the Virgin Mary was actually born in Laclubar, where she was transformed from a civet cat into a human being.

The notion of a primordial unity between humans and the land is crucial to understanding the ways in which people of the region see themselves and their relations to others (both ancestors and foreigners). One of the most striking aspects in the accounts of their return to $\mathrm{Fu}$ nar is the way villagers say that they need to be close to their ancestral land in order to recover well-being and prosperity. Wealth can be obtained by mobilizing the potency of the land, of ancestral objects and houses. The detail of such mobilization is usually kept secret-those making such claims present themselves as conspiring with invisible powers. Yet, being too close to or unified with the ancestral land can also cause anxiety and there was often a lingering fear that outsiders could threaten indigenous sources of prosperity.

The suggestion that there is a secret and empowering source of prosperity and that the control over this source has either been lost or is under threat is also a central theme in many places in Melanesia. Hence a number of authors have suggested that we can describe Timor-Leste's accounts as having cargoistic elements (Kammen 2009; Traube 2007; Duarte 1987-1988). However, although hopes and promises about sudden wealth are clearly expressed in the Laclubar subdistrict, I found little evidence that these were linked specifically to Western goods. 
This was somewhat different in national narratives of oil development that clearly sought to appeal to modernist aesthetics. In both kinds of accounts, the theft of people's source of prosperity was associated with contact with foreigners and, at least in Laclubar, did not lead people to form a movement (millenarian or otherwise) to recover the wealth. How useful, then, is this comparison between visions of prosperity in Timor-Leste and the cargo literature?

Locating any East Timorese/Melanesian phenomenon in terms of cargo cults must take into account the reassessment of this category that has taken place over the last 30 years, in which cargo discourse has come to be seen in terms of the colonial context it served, providing "Europeans with a locally adapted version of a broader colonial myth of indigenous irrationality or counter-productivity" (Buck 1989: 160) or as the product of Western desires (Lindstrom 1993) and generally to be understood in the context of colonial, missionary and early anthropological discourses aimed at constituting and exaggerating the dichotomy between the colonial Self and the indigenous Other (Hermann 2004: 38). The label "cargo cult" reinforced these differences, similar to Pelkmans and Machold's (2011) description of the label "conspiracy theory," which establishes a distinction between rational theories of the powerful and the supposed irrationality of the powerless. The dangers of continuing to use "cargo" as a category and applying it to Timor-Leste risks, on the one hand, perpetuating derogatory/romantic exoticization, casting Timorese ideas as irrational and, on the other hand, overextending the category analytically such that the phenomena labeled "cargo cults" in Melanesia are so vast that the term loses any explanatory value (Buck 1989: 157; Otto 1999: 88).

For all that, others have argued that, reconfigured, the term captures practices that cannot be ignored (e.g., Lattas 1998; Tabani 2008), and these connect to what I observed in Timor-Leste. One undeniable ethnographic point of connection is the implicit interweaving of biblical accounts into the narratives about future prosper- ity, one example of which was the golden star that showed the first ancestors the way. Similarly the claims about the origins of humanity and the renaming of the first ancestors as Adam and Eve bears some resemblance to the way that Melanesian accounts draw on the Bible. Jorge Barros Duarte described "Hoho-Ulu" in Aileu as the "oldest nativist movement" in Timor-Leste, in existence since the later part of the nineteenth century (Duarte 1987-1988: 45). Connecting Catholicism with "popular local traditions" (Duarte 1987-1988: 47), the movement had its own "little Jesus" (a Timorese boy) and a Virgin Mary (Nossa Senhora), who was said to have been able to transform a kernel of corn into a mound of maize: hence, Duarte argued, the Hoho-Ulu movement had cargoistic elements (1987-1988: 45).

During her fieldwork in Hohul and Raimaus among the Mambai of Timor-Leste in the 1970s and again after the restoration of independence, Elizabeth Traube (2007) recorded narratives about a Christ-like prophet, called Tat Felis, who would have brought prosperity and justice to local people had the ancestors not foolishly driven him away (she may be speaking about the same movement described by Duarte). The possibility of undoing this mistake of the ancestors was connected to utopian hopes of what would be gained from independence, leading Traube (2007: 10) to stress the nationalist potential of these accounts and comparing them to "socalled 'cargo myths." This theme of blocked access makes an interesting connection between Timor-Leste and the millenarian movement of Kaliai in Papua New Guinea, which sees its access to cargo as blocked because of mistakes its "heathen" ancestors made in colonial times that "damaged their relationships with the underground dead" (Lattas 1998: 98). In Lattas's and Traube's work we find that people identify with the suffering of Jesus in order to make sense of inequalities in the present (Lattas 1998: xxxiv$\mathrm{xxxi}$ ), preparing the ground for nationalist mobilization (see Lattas 1998: xxvvii-xxxi; and Tabani 2008: 332-35, who discuss whether cargo cults are proto-nationalist formations; 
see also Worsley 1957). In Laclubar, hopes about future prosperity were not specifically associated with independence and nationalist sentiments, as they were in other areas of TimorLeste (Nygaard-Christensen 2010). In Funar, prosperity would be achieved through reunification with the ancestral land-similar to the way Kiliai in Lattas's ethnography sought prosperity-albeit within a nationalist frameworkby regaining control over the underground world of the dead that the whites had somehow managed to colonize and keep separate from the living (Lattas 1998: 110).

In "Fragments of Utopia," Douglas Kammen describes different types of "utopian visions" that have characterized political thinking in TimorLeste since independence, including "myth(s) of great subterranean riches" (2009: 405). Kammen (2009: 400) discusses a range of different groups in Timor-Leste, whose ideas may be described as millenarian, merging political and religious agendas. There is the antigovernment organization CPD-RDTL, a group called Kolimau 2000 that has associated independence with a moment of radical transformation, and Sagrada Familia, founded by the guerilla fighter L-7, which combines Catholic and ancestral notions of sacred power. These various groups mostly have their origins in the anti-Indonesian resistance and bring together Catholic and indigenous notions of potency, expressing critiques of the postoccupation independent government.

When I first arrived in the Laclubar subdistrict, some residents suggested that I had come to steal gold from ancestral houses. The fear of "losing gold" might similarly represent people's worries about outside interference in their control over local resources. The fear that foreigners had come to Timor-Leste to steal their gold deposits is an inverse analogue of claims made in some of the Melanesian contexts that foreigners are regarded as the lost brother who has come to restore an age of unity after the fragmentation of prosperity or power. In both cases, the relationship to invisible power that can be tapped into to bring prosperity draws on a distinction between self and other. The "others" can be for- eigners or colonizers-but also ancestors, as the literature on the notion of foreigners being returning ancestors illustrates.

Rutherford (2003) has shown how in West Papua, the foreign has come to be seen as a source of wealth, value, and desire, similar to Bubandt's (2004) analysis of how in Maluku the outside is imagined as a vital source of local identity. In contrast, in the Laclubar subdistrict-as elsewhere in Timor-Leste-we find the suggestion that even those who seem foreign may in fact be returning younger brothers. When characterizing the importance of the ancestral land, people emphasize that the land gave birth to the first human beings; it is the source or origin of life. The suggestion that all of humanity originates from this region implies that foreigners also originate there, thus collapsing the distinctions between indigenous people and outsiders. Again we find a point of connection to Melanesian cases, such as the Tuka movement, which not only mobilized the Fijian principle of the power of the people of the land but also held that the ancestors of all-powerful others are emplaced in Fiji (Kaplan 2004: 60, 74). Similarly, in Timor-Leste foreigners are frequently associated with land spirits, which is the same term used for autochthones, "people of the land" (see also Hicks 2004 [1976]: 35-37).

An underlying assumption is thus that there is an original unity of foreigners and autochthones-bound up with the original unity of humans and the land. This could explain why some East Timorese hold that the wealth of foreigners actually belongs to Timor-Leste, since both share a common origin (e.g., at Balulin, the "navel" of the land and origin place of humankind). While labels such as "cargo cult" and "conspiracy theory" reinforce differences between the self and others, such visions of common human origins end up collapsing these distinctions. By doing so, they operate as a critique of power differentials and social inequalities that are implicit in such distinctions-by expressing dreams of millenarian change, people stress they are equally deserving of modern lifestyles. 
Lattas (1998: 103) describes how Melanesian Kaliai believe that it is whites who seek to keep them away from the source of wealth, developing a renewed interest in the underground in order to carve out a sphere not belonging to the Europeans. Reconfigured, this underground world of the dead became "a utopian realm of otherness that would allow people to remake themselves in ways that both mimed and were different from those mimetic processes officially authorized by Europeans" (Lattas 1998: 97). Through ideas about the underground and the various associations of gold and oil, people in Timor-Leste too are creating a place to identify with the wealth and the visions of modernity of the other-creating a space where through something contained deep inside the land, Timorese can be at least as prosperous as the former European colonizers.

\section{Visions of conspiracy}

Attitudes toward the invisible potency of the ancestral land are ambivalent, for it embodies both utopian and dystopian potentialities. For instance, the emphasis on hidden wealth, associated with the underground or with ancestral actions, caused concern that foreigners could try to take this resource away, as mentioned earlier. These concerns were expressed not just toward me but also toward other outsiders. A member of Laclubar's police force, for example, suggested that the US government had a special interest in the region because of the oil resources in Pualaka (near Laclubar Town). I also heard suggestions that the United States was plotting to invade Timor-Leste because of its immense uranium deposits that were allegedly located underground (see also Kammen 2009: 389, 405). Several residents of Laclubar Town told me that the Peace Corps volunteers were actually CIA agents, which was visible in the fact that they owned big satellite phones. Kammen (personal communication) was similarly told by a lecturer at Dili's National University that the United States of America was interested in building a naval base under Atauro, a former prison island north of Dili. A key theme here is the underground and the idea that foreigners are somehow trying to control this sphere (cf. Scott 2011). By seeking to develop the island into a special economic zone, the East Timorese government seems to be reappropriating this space. Those positive visions are countered by prevalent warnings by local nongovernmental organizations (NGOs), as well as international commentators and scholars, about oil dependency and the dangers of the resource curse (for anthropological discussions of the resource curse, see, e.g., Reyna and Behrends 2008; Weszkalnys 2011). Dystopian scenarios of oil dependency present the flipside of more aspirational visions of development from oil wealth.

During my time in Timor-Leste, suspicions toward outsiders, suggestions about conspiracies, or worries about the possible onslaught of mayhem and war intensified during politically unstable times. During the 2007 elections, for example, there were rumors in Laclubar that members of the FRETILIN party were hiding sacks of rice in a secret deposit for distribution to their supporters alone. Several villagers claimed to have heard gunshots during the night and alluded to the possibility of terrible and unspeakable things happening in the future. On a number of occasions while discussing the tense political situation in the capital city Dili, friends in Funar told each other with a sense of panic to be quiet in case others might be listening. Such suspicion and mistrust were certainly connected to the experiences of Indonesian occupation, when there was a constant and very real danger of people being accused of supporting the resistance and shots were indeed fired at night.

Rumors and suspicions contained both a realistic and a "dystopian" element. In 2006, violence erupted in the capital city Dili after disagreements within the military led to more widespread regional conflicts, the collapse of the main state institutions, and an official request for the intervention of an international military peacekeeping force. During the so-called krise, 
videos and photos by the rebel leader Alfredo Reinado were circulated throughout the country, which further fueled fears, rumors, and concerns about national conspiracies. People in Funar were convinced, for example, that Reinado was hiding nearby and the general anxiety was intensified by the fact that helicopters, suspected to be carrying armed military personnel, were regularly flying low over the village. During this period, people mentioned anxiously and on a near daily basis that they thought a very big war would break out-a war that would be unlike anything they had experienced before. At the same time, there were rumors that a pig had given birth to an elephant. The pig story was a topic of daily conversation-it expressed the total mayhem and disorder people were expecting. This, people said, was a "sign" that much worse was to come. In the same vein, a number of villagers claimed that the "Three Lakes" (Tasi Tolu) near Dili had all turned blood red, a rumor that originated in the capital city. For some, lakes filled with blood were a sign of impending war and the return of unthinkable mayhem to Timor-Leste, while others reasoned that they represented terrible massacres that had already happened in the context of the 2006 conflicts.

Maj Nygaard-Christensen (2012: 222-223) has examined the perception of Reinado as the "rebel" leader, opposed to that of the "diplomat" José Ramos Horta. She stresses that at the time when Reinado was in hiding, rumors were circulating about his magical strength: Black Hawks shot bullets at him "like rain," but he remained unharmed. Claims were made that magical protection had allowed him to become invisible, thereby tapping into accounts of the resistance and the anticolonial struggle. For some, Reinado was destabilizing the country. According to others, Reinado was the true democrat, associated with transparency (Nygaard-Christensen 2012: 224), someone who fought against dirty state politics. The representation of Reinado (with his magical powers) as the true defender of democracy, Nygaard-Christensen (2010: 225) argues, reintroduced a spiritual element into seemingly secular politics.
Dystopian fears tend to increase in times of conflict, such as the krise of 2006, in which the rebel Reinado was a major figure. As in other nearby conflict zones-these rumors clearly had the potential to amplify existing tensions, as shown by Kirsch (2002) in the case of Indonesiaoccupied West Papua. Nils Bubandt (2004) has documented Maluku millenarian narratives circulating in 1999 predicting an upcoming battle the following year between Christians and Muslims that would lead to a radical transformation of the world, which fueled violence between them. Similarly, in the 2006 conflict in TimorLeste, rumors that unknown forces were instigating violence often created extreme anxiety. Emotionally and politically charged rumors about invisible sources of power and potency continued to circulate across the country for years afterwards and periodically led to the eruption of small conflicts between different factions.

In 2008, Alfredo Reinado was killed by José Ramos Horta's security guard, after he had staged an attack on José Ramos Horta (former president of the country and Nobel-peace prizewinner) near his residence in Dili. This gave rise to yet another range of suspicions. Why was Ramos Horta shot and critically injured, while Prime Minister Xanana Gusmão escaped unscathed when another party of rebels arrived at his house the same day? Was Reinado shot in defense or was he, in fact, executed? A range of rumors circulated in the weeks after the event, expressing suspicions that the entire attack had been a setup, designed to get rid of Reinado. Several people told me that they are certain that Reinado is actually still alive-hiding, and this is interesting considering the significance of the underground in visions of prosperity-in a hole in the ground.

Suspicions of conspiracies and cover-ups more often than not spill across national boundaries, and conspiracies can be confirmed by facts of history (see, e.g., Jolliffe 2001). Worries that foreigners may come to enrich themselves through Timor-Leste's resources clearly have an element of truth to them. Neves (2006) has pointed out how billions of US dollars that 
were invested in postconflict state building in Timor-Leste were in fact spent on the salaries of international staff. He shows that international staff working for the UN transitional government were paid 20-30 times more than their local counterparts, who received less than 1 percent of the total UNTAET budget (the UN Transitional Administration in East Timor). Moreover, in June 2014, US federal agents arrested an American adviser who had defrauded the Timor-Leste government of US $\$ 3.5$ million (La'o Hamutuk 2014).

Accounts of the possibility of sudden wealth and fears of its theft seem to emerge precisely at moments when people are confronted with outsiders, whose presence is experienced as explicitly extractive. The suggestion that foreigners have come to steal gold, oil, or other resources reflects to an extent the actual theft of natural resources from Timor-Leste. Portuguese colonizers, whose imperial expansion was partly motivated by a quest for gold (Boxer 1969: 164167)_itself a utopian vision of prosperityparticipated in the systematic exploitation of Timor-Leste's natural resources, including sandalwood. Later, Australian companies repeatedly came to the country to survey its natural resources (Pélissier 1996: 241; see also McGrath 2014), while Indonesia bought Australia's silence concerning the occupation by promising Australia access to East Timorese oil resources. Independence has been accompanied by an economic bubble created by an influx of staff working for the World Bank, UN, and other aid agencies, which led to the construction of expensive hotels and apartments and large-scale migration of the rural population to the cities, where youths find low-skilled work in construction and in the service sector, often as domestic laborers for the aid community. Social inequalities are rising sharply in the country, and the economic elite is increasingly estranged from the ordinary population. Large churches, government buildings, and foreign embassies have sprung up in the capital, while the majority of people live in extremely poor conditions. It is not surprising that wealthy East Timorese citi- zens or those in government positions are sometimes referred to as "foreigners" (malae). The stark inequality and difference of living standards does quite understandably raise the question whether foreigners somehow profit from Timor-Leste's wealth. Australia still makes claims to oil and gas that, according to international maritime law, would belong to Timor-Leste. In that sense, the fear that foreigners may come to take people's wealth away seems a legitimate one. This raises the question of whether or not there is some truth to at least some of the so-called conspiracy theories circulating in the country.

A qualifying feature of the label "conspiracy theory" is the fact that the content of such a theory must by definition be untrue. The label is often used in a pejorative way to describe what are considered to be absurd ideas or theories of plots that threaten to destabilize the current world order. From the perspective of those using the label, conspiracy theorists connect unrelated events, suspect implausible sinister plots behind the visible world of everyday interactions, or allege cover-ups of illegal activities by those in charge; they are, in other words, irrational or fantastical (Pelkmans and Machold 2011: 74). Conspiratorial allegations are usually considered to be false or unproven, because if they turned out to be true, they would no longer be seen as a conspiracy theory but would simply count as reality. As Pelkmans and Machold (2011: 76-77) have suggested, there is no epistemological difference between conspiracy theories and other theories, yet the label "conspiracy theory" is often a tool used by those in power to discredit the critiques of those at the margins.

In their analysis of conspiracy theories in relation to the buzzword of the aid industry "transparency," West and Sanders describe conspiracy theories as ideological formations that often express "suspicion of power," whether from the left or the right $(2003: 3,15)$. West and Sanders discount the need to evaluate conspiracy theories in terms of their truth-value, something they feel anthropologists still tend to do nowadays. But what if conspiracy theories do turn out to be true? What if the suspicions about 
cover-ups, agitation behind the scenes, or illegal spying end up being grounded in reality? Can we really dismiss the significance of the truthvalue of conspiracy theories? There are probably few other places in the world where alleged conspiracies have been revealed to be based on actual conspiratorial activity as frequently as in Timor-Leste.

On 3 December 2013 the Australian Security Intelligence Organisation (ASIO) raided the office of a Canberra-based lawyer, Bernard Collaery, who was preparing a case against the Australian government on behalf of TimorLeste. The ASIO seized documents that contain information related to the legal battle over US $\$ 40$ billion in oil and gas reserves located in the Timor Sea (Lamb 2014; McGrath 2014). It had just been revealed that nearly 10 years earlier, in 2004, when negotiations were going on between both governments, Australian spies posing as aid workers had planted recording equipment to listen in on the Timor-Leste government. When one of the spies later blew the whistle, the Timor-Leste government took Australia to the International Court of Justice to challenge the treaty that both countries had entered into in 2006. The so-called Certain Maritime Arrangements in the Timor Sea (CMATS) treaty contained a clause preventing renegotiation for 50 years. However the revelation of espionage opened the door for Timor-Leste to take action to challenge the treaty, which attributed only 50 percent of revenues from the Timor Sea offshore oil and gas reserves to TimorLeste, with the other 50 percent going to Australia, even though the fields should belong to Timor-Leste if the laws of international maritime boundaries were applied (McGrath 2014; Robie 2014).

These events illustrate, as Pelkmans and Machold (2011: 68) have argued, that we should not dismiss the significance of the truth-value of conspiracy theories all too quickly. When conspiracy theories turn out to be fully or partially confirmed by the facts of history, it provides those who hold them with a sense of vindication. It influences the bargaining position of af- fected parties and thus shapes the field of power relations within which such theories emerged in the first place. The revelations about the Australian spies made it possible for the Timor-Leste government to challenge the maritime agreement that had previously been untouchable due to the 50-year nonrenegotiation clause. It seems that East Timorese suspicions of Australian conspiracies were entirely warranted. Of course, this does not mean all conspiratorial suspicions voiced in Timor-Leste are true, but it does mean that they should not a priori be described as irrational, fantastical, or absurd.

During my research on petroleum development in 2015, a ritual speaker in Suai, the region where part of Timor-Leste's petroleum infrastructure project is to be built, asserted that he possessed documents about an agreement the "affected community" made with the government about profit sharing, but he said that it was secret. He told me that if he showed it to me, I might tamper with it or steal it; after all, the Australian government had just stolen documents from the East Timorese government. Allusions to the Australian spying scandal were ample, and elaborated in much detail during my visit to the south coast. Members of the government and the oil industry made similar kinds of claims, maintaining that they had knowledge of a document containing proof that Timor-Leste had new yet undiscovered onshore petroleum resources, subsequently adding that these documents had to be kept secret for the time being.

\section{Conclusion: Cargo and conspiracy as critical practice}

West and Sanders (2003: 6) have argued that conspiracy theories are frequently linked to ideas of unseen powers or embedded in "occult cosmologies"-something that, in the case of Timor-Leste, can equally be said about utopian visions. People who make such claims about the invisible workings of power often also hint at the possibility that these unseen powers can be manipulated or tapped into. Gold, oil, and lulik 
are considered to be sources of immeasurable wealth and potential-as well as anxiety and antagonism. In the collective imagination, the properties of oil and gas increasingly come to resemble that of lulik powers with its potential to usher in change and bring prosperity, while also making the country vulnerable to foreign exploitation. The magical potential ascribed to the sacred power of the land is transposed onto petroleum (cf. Weszkalnys 2014), able to bring immense wealth but also conjuring images of oil dependency and the resource curse. Fears of conspiracy and utopian visions of prosperity therefore present two sides of the same coin and are rooted in the notion that power works in invisible ways. Whereas conspiracy theories claim that others are secretly plotting, some individuals in Timor-Leste also saw themselves as the guardians of a hidden potency, a source they actively seek to keep hidden-or only reveal to a select number of individuals.

Presenting themselves as having access to secret knowledge or power may be a way of countering marginalization and challenging political asymmetries. At the national level, the politicians involved in the planning of the petroleum infrastructure project are, of course, not marginal-they are members of the elite. Yet internationally they are faced by a massively powerful petroleum industry and are forced to negotiate with Australia from very uneven negotiating positions. In order to make any progress in negotiations with Australia, they need to "play the game" as the minister of petroleum and mineral resources (Alfredo Pires) told me in an interview-and asserting knowledge over hidden riches might be one part of this strategy. Being able to project confidence in the existence of great resource wealth is a key aspect of "playing the game" as it is a precondition for attracting investors. But with rapidly falling oil prices, prospects of fueling development in Timor-Leste through oil wealth are becoming increasingly uncertain.

This article has sought to distinguish between labels and practice. The use of the labels "cargo cult" and "conspiracy theory" has the effect of creating a divide between supposedly rational and irrational people, distinctions that are frequently mapped onto colonial distinctions of foreign colonizers versus (post)colonial indigenous population. Representing people as conspiracy theorists is a way of blocking them from making inquiries about foreign interventions, including spying. Representing state planners as cargo cultists may in the end serve to undermine their bargaining position in the competitive and hard-line oil business. Reyna and Behrends (2008: 12) have emphasized that discussions about the curse of oil in developing petrostates should be investigated in terms of "struggles to regulate domination." The ripple effects of oil's domination globally are visible in the fact that in their frustration at their marginal position internationally, state planners ignore legitimate warnings about the risks of the resource curse on their national economy.

In contrast to labeling, the practices of envisioning prosperity and conspiracy present ways of engaging critically with power inequalities: by portraying outsiders as ultimately originating in Timor-Leste or by identifying Timorese selves with the wealth of the outside, these problematic categories are extinguished. These visions end up collapsing such distinctions by appropriating the power of the outside. It is, I would argue, part of larger struggles over authorityboth among different political groups inside Timor-Leste and of the country's relationship with the outside, such as powerful neighbors like Australia. By making references to this hidden power, people in Timor-Leste allude to the hidden possibilities for action that those at the margins possess. Sadly, in the long term, however, the "outsider focus" of the fantastical development schemes the government is planning to implement in Oecussi and along the south coast (plans that include international airports, hotels, and a hospital for medical tourists) is more likely to widen the gap between East Timorese citizens and outsiders, as argued convincingly by Meitzner Yoder (2015: 312).

Even though I would reject the use of the term "cargo cult" to describe visions of pros- 
perity in Timor-Leste, there are certain commonalities about the ways in which people in Timor-Leste and Melanesia have responded to drastic historical transformations, including interaction with Europeans, colonial exploitation, the introduction of Christianity and the persistence of social inequalities (Robbins 2004). In his reassessment of anthropological critiques of the notion of cargo cults and millenarianism in Melanesia, Joel Robbins (2004: 243) has argued that millenarian (or cargoistic) practices can be "reconfigured as part of a comparative anthropology of critical practice." This insight can be applied to the literature on conspiracy theories as well, since such theorizing about conspiracies should be seen as a similar form of critical practice. By discussing visions of prosperity alongside visions of conspiracy, this article has tried to further extend this critical comparative project-whereas visions of conspiracy tend to focus on political inequalities, visions of prosperity tend to be critical of economic differences. Both kinds of visions have a "sense-making value" (Pelkmans and Machold 2011: 77) and aim to make inexplicable dynamics that have led to the unequal distribution of power and wealth comprehensible. As such, practices of envisioning prosperity and conspiracy in Timor-Leste should be seen as forms of critical inquiry that challenge both national and international power asymmetries. Rather than ridiculing such visions, we should take their critical potential seriously, so that we can analyze under what conditions such forms of critical practice manage to change the relations of inequality from which they arise.

\section{Acknowledgments}

An earlier draft of this paper was presented at the Esfo 2010 panel "Voices in contemporary cargoistic discourse," and I am grateful to the participants and especially the organizer, $\mathrm{Mi}$ chael Scott, for their constructive feedback. For their comments on earlier drafts I also thank Janet Gunter, Douglas Kammen, Ricardo Roque,
Fidelis Magalhães, Henri Myrtinnen, Andrew Sanchez, James Scambary, Perig Pitrou, and Mathijs Pelkmans. Most important, I would like to thank all participants in my field research in Timor-Leste. This article draws on research funded by the Economic and Social Research Council of the UK (grant no. ES/L010232/1), whom I thank for their generous support.

Judith Bovensiepen is a senior lecturer in social anthropology at the University of Kent in the UK. She has been conducting research in Timor-Leste since 2005, has published articles on politics and religion in the postoccupation period, and is currently working on a research project about the politics of oil. Her book The land of gold: Post-conflict recovery and cultural revival in independent Timor-Leste was published in 2015.

Email: J.M.Bovensiepen@kent.ac.uk

\section{References}

Aarons, Mark. 2006. Beloved companheiros: What happened in East Timor. The Monthly, August: 24-31, http://search.informit.com.au/ documentSummary; $\mathrm{dn}=200609184$;res=IELAPA. Bovensiepen, Judith, Monis Filipe, and Flaviano Freitas. Forthcoming 2016. Expectations of development: The Tasi Mane project in SuaiCovalima. In Timor-Leste: The local, the regional, the global. Dili: Timor-Leste Studies Conference Proceedings. Hawthorn: Swinburne Press.

Bovensiepen, Judith. 2015. The land of gold: Post-conflict recovery and cultural revival in independent Timor-Leste. Ithaca: Cornell Southeast Asia Program Publications.

Boxer, Charles R. 1969. The Portuguese seaborne empire: 1415-1825. London: Hutchinson and Co.

Bubandt, Nils. 2004. Violence and millenarian modernity in Eastern Indonesia. In Holger Jebens, ed., Cargo, cult, and culture critique, pp. 92-116. Honolulu: University of Hawaii Press.

Buck, Pem D. 1989. Cargo cult discourse: Myth and the rationalization of labor relations in Papua 
New Guinea. Dialectical Anthropology 13(2): $157-71$.

Duarte, Jorge B. 1987-1988. O fenómene dos movimentos nativistas. Série de Antropobiologia: Revista do Instituto de Investigação Cientifica Tropical 5(1-2): 41-52.

Hermann, Elfriede. 2004. Dissolving the self-other dichotomy in Western "cargo cult" constructions. In Holger Jebens, ed. Cargo, cult, and culture critique, pp. 36-58. Honolulu: University of Hawaii Press.

Hicks, David. 2004 [1976]. Tetum ghosts and kin: Fertility and gender in East Timor. 2nd ed. Long Grove: Waveland.

Jebens, Holger, ed., 2004. Cargo, cult, and culture critique. Honolulu: University of Hawaii Press.

Jolliffe, Jill. 2001. Cover-up: The inside story of the Balibo Five. Brunswick, Australia: Scribe Publications Pty Limited.

Kammen, Douglas. 2009. Fragments of utopia: Popular yearnings in East Timor. Journal of Southeast Asian Studies 40(2): 385-408.

Kaplan, Martha. 2004. Neither traditional nor foreign: Dialogics of power and agency in Fijian history. In Holger Jebens, ed., Cargo, cult, and culture critique, pp. 59-78. Honolulu: University of Hawaii Press.

Kirsch, Stuart. 2002. Rumor and other narratives of political violence in West Papua. Critique of Anthropology 22(1): 53-79.

Lamb, Kate. 2014. ICJ orders Australia to stop spying on Timor-Leste. Special Broadcasting Service (SBS), Australian new broadcaster, http://www.sbs.com.au/news/article/2014/03/04/ icj-orders-australia-stop-spying-east-timor.

La’o Hamutuk. 2014. Bobby Boye: Convict, Advisor and Fraud. 16 September, http://www.laohamu tuk.org/econ/corruption/Boye/14BoyeCase.htm.

Lattas, Andrew. 1998. Cultures of secrecy: Reinventing race in Bush Lakiai cargo cults. Madison: University of Wisconsin.

Lindstrom, Lamont. 1993. Cargo cult: Strange stories of desire from Melanesia and beyond. Honolulu: University of Hawaii Press.

McGrath, Kim. 2014. Oil, gas and spy games in the Timor Sea. Australian scheming for the Greater Sunrise oilfield has a long history. The Monthly, April, https://www.themonthly.com.au/issue/ 2014/april/1396270800/kim-mcgrath/oil-gasand-spy-games-timor-sea.
Meitzner Yoder, Laura S. 2015. The development eraser: Fantastical schemes, aspirational distractions and high modern mega-events in the Oecusse enclave, Timor-Leste. Journal of Political Ecology 22: 299-321.

Neves, Guteriano Nicolao S. 2006. The paradox of aid in Timor-Leste. Paper presented at Cooperação Internacional e a Construção do Estado no Timor-Leste, University of Brasilia, Brazil, July 25-28.

Nygaard-Christensen, Maj. 2010. When utopia fails: Political dreams and imaginaries of democracy in Timor-Leste. Unpublished PhD diss., Aarhus University.

Nygaard-Christensen, M. 2012. The Rebel and the diplomat: Revolutionary spirits, sacred legitimation and democracy in Timor-Leste. In Nils Bubandt and Martjn van Beek, eds., Varieties of secularism in Southeast Asia: Anthropological explorations of religion, politics, and the spiritual, pp. 209-229. New York: Routledge.

Otto, Ton. 1999. Cargo cults everywhere? Anthropological Forum 9(1): 83-98.

Pélissier, René. 1996. Timor en guerre: Le crocodile et les portugais, 1847-1913. Orgeval: René Pélissier.

Pelkmans, Mathijs, and Rhys Machold. 2011. Conspiracy theories and their truth trajectories. Focaal: Journal of Global and Historical Anthropology 59: 66-80.

Reyna, Stephen, and Andrea Behrends. 2008. The crazy curse and crude domination: Toward an anthropology of oil. Focaal: Journal of Global and Historical Anthropology 52: 3-17.

Robbins, Joel. 2004. On the critique in cargo and the cargo critique: Toward a comparative anthropology of critical practice. In Holger Jebens, ed. Cargo, cult and culture critique, pp. 243-260. Honolulu: University of Hawaii Press.

Robie, David. 2014. Timor-Leste takes on Australia in "rip off" spy case with country's future on line. Pacific Media Centre. 20 January, http:// www.pmc.aut.ac.nz/articles/east-timor-takesaustralia-rip-s.

Rutherford, Danylin. 2003. Raiding the lands of the foreigners: The limits of the nation on an Indonesian frontier. Princeton: Princeton University Press.

Scott, Michael W. 2011. The Makiran underground army: Kastom mysticism and ontology politics in South-east Solomon Islands. In Edvard Hviding and Knut M. Rio, eds., Made in Oceania: Social 
movements, cultural heritage and the state in the Pacific, pp. 195-222. Wantage: Sean Kingston Publishing.

Tabani, Marc. 2008. A political history of Nagriamel on Santo, Vanuato. Oceania 78(3): 332-57.

Traube, Elizabeth G. 2007. Unpaid wages: Local narratives and the imagination of the nation. Asia Pacific Journal of Anthropology 8(1): 9-25.

West, Harry G., and Todd Sanders. 2003. Power revealed and concealed in the New World Order. Introduction to Harry G. West and Todd Sanders, eds., Transparency and conspiracy: Ethnographies of suspicion in the New World Order, pp. 1-38. Durham: Duke University Press.
Weszkalnys, Gisa. 2011. Cursed resources, or articulations of economic theory in the Gulf of Guinea. Economy and Society 40(3): 345-372.

Weszkalnys, Gisa. 2014. Oil's magic: Contestation and materiality. In S. Strauss, S. Rupp, and T. Love, eds., Cultures of energy. Power, practices, technologies, pp. 267-283. Walnut Creek: Left Coast Press.

Worsley, Peter. 1957. The trumpet shall sound: A study of "cargo" cults in Melanesia. London: MacGibbon and Kee. 